\title{
Culture of dental pulp stem cells on nanoporous alumina substrates modified by carbon nanotubes
}

This article was published in the following Dove Medical Press journal:

International Journal of Nanomedicine

\author{
Ameneh Alizadeh' \\ Amir Razmjou' \\ Mehrorang Ghaedi² \\ Ramin Jannesar ${ }^{3,4}$ \\ Fahimeh Tabatabaei $i^{5,6}$ \\ Vahid Pezeshkpour ${ }^{3,4}$ \\ Lobat Tayebi ${ }^{5}$ \\ 'Department of Biotechnology, \\ Faculty of Advanced Sciences and \\ Technologies, University of Isfahan, \\ Isfahan, Iran; ${ }^{2}$ Department of \\ Chemistry, Yasouj University, Yasouj, \\ Iran; ${ }^{3}$ Department of Pathology, Yasuj \\ University of Medical Sciences, Yasuj, \\ Iran; ${ }^{4}$ Department of Biotechnology \\ and Microbial Nanotechnology, \\ Dena Pathobiology Laboratory, Yasuj, \\ Iran; ${ }^{5}$ Marquette University School \\ of Dentistry, Milwaukee, WI, USA; \\ ${ }^{6}$ Department of Dental Biomaterials, \\ School of Dentistry, Shahid Beheshti \\ University of Medical Sciences, \\ Tehran, Iran
}

Correspondence: Amir Razmjou Department of Biotechnology, Faculty of Advanced Sciences and Technologies, University of Isfahan, Isfahan, Hezar jarib St., Isfahan 8I7467344I, Iran Tel +983I3793 440 I

Email a.razmjou@ast.ui.ac.ir

Mehrorang Ghaedi

Department of Chemistry, Yasouj

University, Pasdaran St., Yasouj

759I87483I, Iran

Tel +98 917 |22 433|

Emailm_ghaedi@mail.yu.ac.ir
Purpose: Alumina substrates are one of the commonly used scaffolds applied in cell culture, but in order to prevent formation of biofilm on the alumina substrate, these substrates are modified with carbon nanotube.

Methods: The alumina substrate was made by a two-step anodization method and was then modified with carbon nanotubes by simple chemical reaction. The substrates were characterized with FTIR, SEM, EDX, 3D laser scanning digital microscope, contact angle (CA) and surface free energy (SFE). To determine how this modification influences the reduction of biofilm, biofilm of two various bacteria, Escherichia coli (E.coli) and Staphylococcus aureus (S. aureus), were investigated.

Results: The biofilm on the modified substrate decreased due to the presence of carbon nanotubes and increased antibacterial properties. Dental pulp stem cells (DPSCs) were cultured onto flat alumina (FA) and nanoporous alumina-multiwalled carbon nanotubes (NAMC) substrates to examine how the chemical modification and surface topography affects growth of DPSCs. Conclusion: Cell attachment and proliferation were investigated with SEM and Presto Blue assay, and the findings show that the NAMC substrates are suitable for cell culture.

Keywords: alumina scaffold, dental pulp, biofilm, adhesion, proliferation

\section{Introduction}

The first goal of tissue engineering is the development of materials that retain or better the tissue function. ${ }^{1,2}$ Selection of proper cells, 3D substrates, and induction of suitable signal for regeneration tissues are important principles of tissue engineering. Thus, stem cells (SCs) are the first step for research in this field. ${ }^{3,4}$ Fetal and mature SCs, which are derived from adult differentiated somatic cells, have been examined in literature. ${ }^{5,6}$ Dental pulp SCs (DPSCs) are another alternative of SCs that can simply be obtained. Dental pulp is connective tissue that contains blood vessels, veins, mesenchymal cells, lymphatic vessels, nerves, and intercostal fluid. ${ }^{7,8}$ DPSCs are useful in bone regenerative therapy. This merit is due to high proliferation, mineralization ability, self-renewal potential, low immunogenicity, and a multipotent differentiation capacity. ${ }^{9-14}$ DPSCs have higher angiogenic, neurogenic, and regenerative potential compared with bone marrow SCs, ${ }^{15}$ which makes them an appropriate SC source for tissue repair and cellular therapies. DPSCs are a good option for regenerative therapy, because they can be easily expanded to produce the required number of cells for the production of graft materials. ${ }^{16}$ These cells can be simply obtained, in comparison with bone marrow SCs, because exfoliated deciduous teeth and impacted third molar teeth are often extracted for clinical or orthodontic reasons..$^{9,17-20}$ Dental SCs are known to differentiate into various cell lineages, such as osteoblasts, chondrocytes, adipocytes, odontoblasts, neural cells, 
and myocytes, among others ${ }^{8,21,22}$ DPSCs offer regenerative potential of various damaged or lost tissues and organs, including dentin, pulp, periodontal tissue, bone, neuronal tissue, blood vessels, muscle, cartilage, hair follicle, and cornea. ${ }^{23}$ Cell-scaffold interactions, cell response, activity, attachment, morphology, and proliferation rely on the properties of culture environment of cells. ${ }^{24}$ Surface wettability and roughness are important factors that could influence protein attachment and cell response. ${ }^{25,26}$ It is reported that cells sometimes grow better on hydrophilic surfaces and sometimes on hydrophobic surfaces. ${ }^{25}$ Biocompatible nanoporous alumina (NA) substrates with high porosity and nano-sized pores are suitable substrates for the cultivation type of cells. The porous nature of these substrates allows the storage of nutrients on both adjacent cells. ${ }^{27}$ Biofilm is a serious problem in biomedical applications. Biofilm can grow on medical devices implanted in the body, such as artificial heart valves, artificial joint, or catheters, and leads to severe infections. When the surface of the alumina substrate is refined, the biofilm is decreased and its biomedical applications are increased. ${ }^{28}$ Swan et al demonstrated that NA with pore size of $72 \mathrm{~nm}$ was favorable for osteoblast adhesion. ${ }^{29}$ Song et al proved that NA was able to promote the adhesion and proliferation of mesenchymal SCs. ${ }^{2}$ These reports indicated that NA could be used as an ideal cell culture scaffold in tissue engineering.

In this research, the substrate surface of alumina has been modified with carbon nanotubes (CNTs), which prevents bacterial adhesion and enhances cell culture. CNTs possess sheets of graphite, which has high mechanical strength, flexibility, and electrical conductivity when rolled into a cylinder, which can be contributed to the hexagonal structure and configuration of $\pi$ electrons. ${ }^{30} \mathrm{CNT}$, with increasing roughness and hydrophilicity, provides a suitable surface for cell culture. Also, CNT tends to bind with proteins of the extracellular matrix, like fibronectin and vitronectin, so it controls cell behavior. ${ }^{31}$ So far, CNT has been a subject of studies for culture of various SC lines, such as neural, embryonic, and mesenchymal SCs. ${ }^{31-35}$ For the first time, we study the response of DPSCs cultured on a substrate of alumina-CNTs, in comparison with flat alumina (FA), and evaluate the effects of hydrophilicity and topography on linkage and the increase of cells on the substrate.

\section{Materials and methods Materials}

Crystal violet and aluminum foil $(99.99 \%$ Al) were bought from Cib biotech Co (Tehran, Iran) and Kingcheng (Beijing,
China), respectively. Oxalic acid, phosphoric acid (85\%), perchloric acid (70\%), hydrochloric acid (37\%), nitric acid $(63 \%)$, sulfuric acid, hydrogen peroxide (30\%), ethanol (95.5\%), methanol (95\%), acetone, chromic oxide, sodium hydroxyl, copper chloride (II), Coomassie Brilliant Blue G-250, and dimethyl sulfoxide were purchased from Merck Co. (Darmstadt, Germany). $\mathrm{NaH}_{2} \mathrm{PO}_{4}, \mathrm{Na}_{2} \mathrm{HPO}_{4}$, BSA, MTT reagent, enzymes, Hank's Balanced Salt Solution (HBSS), alpha-minimal essential medium ( $\alpha \mathrm{MEM})$, and FBS were bought from Sigma Aldrich (Darmstadt, Germany). Multiwalled CNTs (MWCNTs) were obtained from CheapTubes (Cambridgeport, VT, USA). FA was obtained from Alfa Aesar (Ward Hill, MA, USA) and studied. Presto Blue (PB) was purchased from Thermo Fisher Scientific (Waltham, MA, USA). Two strains of bacteria containing Escherichia coli (ATCC: 25922) and Staphylococcus aureus (ATCC: 25923) were provided by Pasteur Institute (Tehran, Iran) for biofilm formation.

\section{Preparation of nanoporous alumina- multiwalled carbon nanotubes (NAMC) substrate}

Ordered NA substrates were fabricated by two-step anodization method. ${ }^{36}$ High-purity Al foils (99.99\%) were annealed in air at $600^{\circ} \mathrm{C}$. Then, the aluminum discs were exposed to ultra-sonication in acetone and water. The cleaned aluminum discs were electropolished in $\mathrm{HClO}_{4}$ and $\mathrm{C}_{2} \mathrm{H}_{5} \mathrm{OH}$ in the ratio of 1:4 at $20 \mathrm{~V}$ power supply (MEGATEK, 0-250 V, 0-30 $\mathrm{mA}$ ) for 3 minutes. Afterward, the first anodization was accomplished using solutions of oxalic acid $(0.3 \mathrm{M})$ and phosphoric acid $(0.2 \mathrm{M})$ at $100 \mathrm{~V}$ and $25^{\circ} \mathrm{C}$ for 1 hour. The first anodic layer was removed by phosphoric acid (6\%) and chromic acid $(1.8 \%)$ at $65^{\circ} \mathrm{C}$. The next step of anodization was done using the same electrolyte and voltage as the first step for 5 hours. The residual aluminum was removed by a $\mathrm{H}_{2} \mathrm{O}-\mathrm{HCl}-\mathrm{CuCl}_{2}$ solution. The barrier layer was eliminated with $5 \% \mathrm{H}_{3} \mathrm{PO}_{4}$. The alumina substrates were immersed in hydrogen peroxide solution $(30 \%)$, then placed in an ultra-sonicator at $80^{\circ} \mathrm{C}$ for 2 hours and rinsed with deionized $\mathrm{H}_{2} \mathrm{O}$. The specimens were put in an oven controlled at $150^{\circ} \mathrm{C}$ for 2 hours. MWCNT was activated in the presence of conventional treatment agents, like concentrated $\mathrm{HCl}$ (37\%) and $\mathrm{HNO}_{3}(63 \%)$, for 24 hours. This treatment led to the appearance of functional groups, including hydroxyl and carboxylic acids. In the next step, the mixture assembly (15 mg of COOH-MWCNT) was thoroughly dispersed in distilled water under sonication. Thereafter, drops of MWCNT 
dispersion were poured on scaffold surface and dried at the room temperature.

\section{Substrate characterization}

Functional groups of the substrates were determined by Fourier-transform infrared spectroscopy (FTIR) (FTIR-8300 Shimadzu Co. Tokyo, Japan) analysis using a KBr disk. The samples were fixed on the holder, and the transmittance spectrum from 400 to $4,000 \mathrm{~cm}^{-1}$ was scanned.

The existence of elements in the substrate and morphology of substrates were analyzed by Energy-dispersive X-ray spectroscope (Hitachi S3400) and scanning electron microscope (SEM; JEOL JSM-6510LV). The surface roughness of the substrates was characterized by a $3 \mathrm{D}$ laser scanning microscope (LSM) (OLS 4000, Olympus Corporation, Tokyo, Japan). Wettability of the substrates was examined by evaluate of water contact angle (WCA) using a Dataphysics OCA 15 plus (Filderstadt, Germany). The surfaces of the substrate samples were characterized using sessile drop technique and Gaosuo software. The average of six CAs was obtained. $\mathrm{H}_{2} \mathrm{O}, \mathrm{C}_{3} \mathrm{H}_{8} \mathrm{O}_{3}$, and $\mathrm{CH}_{3} \mathrm{NO}$ with specified factors (Table S1) were applied to compute the surface free energy (SFE) of the samples by Van Oss method. . $^{37,38}$

\section{Biological tests}

\section{Protein adsorption assay}

The strength and type of cellular attachment to the surface rely on the binding of proteins. The species adsorption on the scaffolds was studied by Bradford protein assay. NAMC and FA substrates were held in a $1 \mathrm{mg} / \mathrm{mL}$ BSA for 4 hours. Then, the residual absorbance was acquired at $555 \mathrm{~nm}$ with a UV-visible spectrometry (V-570 Jasco Co., Hachioji, Tokyo, Japan) after removing the samples. The quantity of the adsorbed BSA on the samples was evaluated according to Razmjou et al. ${ }^{39,40}$ In the Bradford method, to determine the protein of a solution, the standard curve must be drawn with certain concentrations of protein solution.

In the Bradford method, to determine the protein content of a solution, the standard curve must be drawn with certain concentrations of bovine serum albumin (BSA). The light absorption of each sample is determined using a UV-visiblespectrometer at $595 \mathrm{~nm}$. To measure the concentration of protein on the scaffolds, each sample is placed in a $50-\mathrm{mg}$ BSA solution in $50 \mathrm{~mL}$ phosphate buffer. Then, $100 \mu \mathrm{L}$ of solution and $5 \mathrm{~mL}$ of Bradford reagent are mixed. The resulting solution is vortexed and the absorption determined at $595 \mathrm{~nm}$. The absorbance number is placed in the standard curve equation and the concentration of protein is obtained on each sample. ${ }^{39,40}$

\section{Bacteria adsorption assay}

The biofilm formation on the substrates was examined by using $E$. coli and $S$. aureus as model microorganisms. The bacterial strains were cultured overnight in a Muller Hinton broth medium (MHBM) at $37^{\circ} \mathrm{C}$ with $150 \mathrm{rpm}$. The overnight bacterial suspensions were diluted with fresh and sterilized MHBM to determine the concentration of $1.5 \times 10^{8} \mathrm{CFU} / \mathrm{mL}$ by measuring the absorbance at $625 \mathrm{~nm} .{ }^{41}$ The substrate samples were sterilized with $\mathrm{C}_{2} \mathrm{H}_{5} \mathrm{OH} 75 \%$ and dried. Then the substrates were immersed inside the tubes containing bacterial suspension and incubated at $37^{\circ} \mathrm{C}$ for 10 days. After 10 days, $2 \mathrm{~mL} \mathrm{CH}_{3} \mathrm{OH}(99 \%)$ and then $2 \mathrm{~mL}$ crystal violet $(0.3 \%)$ was added. After 5 minutes, incubation scaffolds were washed by MilliQ-water. At the end, the substrates were analyzed by SEM.

\section{Flow cytometry}

Flow cytometry was applied to study the impact of the modification on the integrity of cell membranes. Cell particles and cell adhesion were also analyzed via flow cytometry method. A bacterial suspension of $1.5 \times 10^{8} \mathrm{CFU} / \mathrm{mL}$ was prepared. The scaffolds were sterilized; then they were placed in a plate containing bacterial suspension overnight at $37^{\circ} \mathrm{C}$. Then, the samples and fresh MHBM were sonicated for 30 seconds to create a bacterium of optimal concentration. To determine the live and dead cells, $5 \mu \mathrm{L}$ of propidium iodide (PI) $(1 \mathrm{mg} / \mathrm{mL})$ was added to a combination of the sample $(50 \mu \mathrm{L})$ and the deionized water $(5 \mathrm{~mL})$. After 10 minutes incubation in the dark, the levels of bacterial adhesion were investigated with the flow cytometry technique (BD Biosciences, San Jose, CA, USA) and were interpreted by Flowjo software. ${ }^{42}$

\section{DPSCs culture}

DPSCs were taken from the pulp tissue for evaluation of cell culture on the specimens. For this, impacted third molars were rinsed with PBS, including streptomycin and penicillin, then cut into small fragments in a sterile dish. An enzyme solution containing dispase and collagenase I in HBSS was mixed with the tissue for 1 hour at $37^{\circ} \mathrm{C}$. $\alpha M E M$ enriched with FBS and antibiotic (antibiotic/antimycotic 100X [Sigma, St Louis, MO, USA] contains 10,000 units penicillin, $10 \mathrm{mg}$ streptomycin, and $25 \mu \mathrm{g}$ amphotericin B per mL.) was added 
to cell suspension and incubated. The fourth passage of cells was used for experiment. The substrates were sterilized with $75 \%$ ethanol, then washed with PBS for 15 minutes and dried. Smooth aluminum was applied as a control. The cell suspension, in an amount of $2 \times 10^{5}$ cells in $100 \mu \mathrm{L}$ culture media, were cultured onto the substrates and incubated for 2 hours.

The cells were isolated from the tissue of patients without knowing their identities.

\section{Cell adhesion}

The morphology and attachment of cells on the substrates were investigated by SEM. For this purpose, cells were fixed in glutaraldehyde $2.5 \%$ and subsequently in $2 \%$ osmium tetroxide for 2 hours. After rinsing with buffer, dehydration with alcohol of different percentages $(30 \%$, $50 \%, 70 \%, 80 \%, 90 \%$, and $100 \%$ for 5-15 minutes each) and air drying, substrates were assessed under SEM (JEOL JSM-6510LV).

\section{Cell proliferation}

The measurement of cell proliferation with $\mathrm{PB}$ reagent was performed at 1 and 7 days. In brief, scaffolds were rinsed with PBS, the reagent was added to $10 \%$ of the culture medium and incubated at $37^{\circ} \mathrm{C}$. A total of $100 \mu \mathrm{L}$ samples of the culture medium were eliminated and transferred to a 96-well plate, and the proliferation was determined using a microplate reader (Synergy HTX, BioTEK, Winooski, VT, USA).

\section{Statistical analysis}

Data of experiments were shown as average \pm SD. To compare the results of groups, $t$-test statistical analysis was done. Cell adhesion is qualitative, and it was performed at two time points with two samples for each group. Cell proliferation was performed at two time points with six samples per group.

\section{Results and discussion Substrate characterization}

Figure 1A shows FTIR spectrum of the control substrate. Adsorption peaks around 1,625 and $3,450 \mathrm{~cm}^{-1}$ are indicative of bending and stretching vibrations of the O-H groups. ${ }^{43}$ The specific peaks at $515-730 \mathrm{~cm}^{-1}$ show the $\mathrm{Al}-\mathrm{O}-\mathrm{Al}$ bond. ${ }^{44}$ Figure $1 \mathrm{~B}$ shows the peaks at 2,924 and 2,854 $(\mathrm{C}-\mathrm{H}), 1,630(\mathrm{C}=\mathrm{C})$ and $1,620\left(\mathrm{COO}^{-}\right) \mathrm{cm}^{-1} .45,46$ The carboxylates groups of the MWCNT are bonded to the hydroxyl alumina. ${ }^{47,48}$ Figure 2A-D shows SEM images and data EDAX of the FA and NAMC substrate. Figure 2A

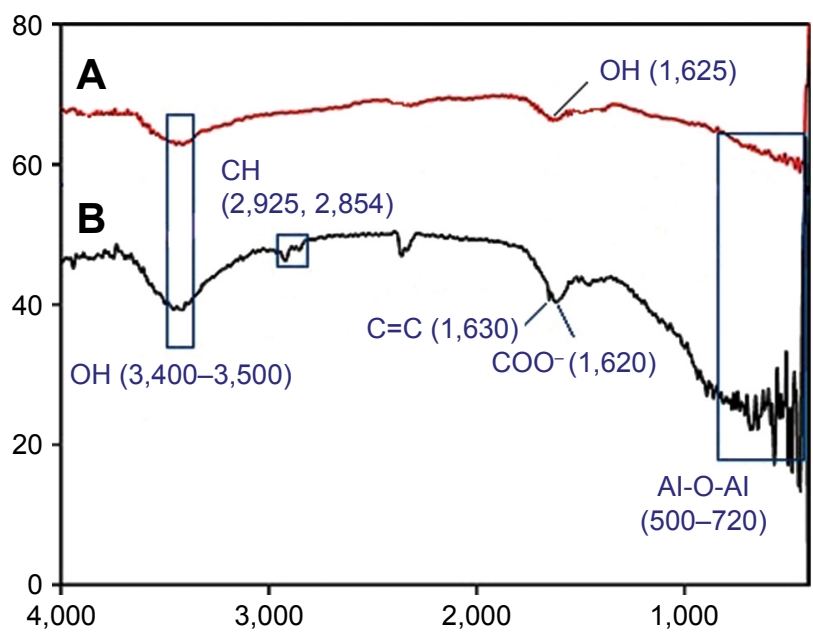

Figure I Fourier-transform infrared spectrum of (A) flat alumina and (B) nanoporous alumina-carbon nanotubes.

and B shows EDAX data of FA and NAMAC. EDAX data shows the existence peaks $\mathrm{O}(0.50 \mathrm{keV})$ and $\mathrm{Al}(1.50 \mathrm{keV})$ for FA and $\mathrm{C}(0.27 \mathrm{kev}), \mathrm{O}(0.50 \mathrm{keV})$, and $\mathrm{Al}(1.50 \mathrm{keV})$ for NAMC. Figure $2 \mathrm{C}$ shows SEM image of FA, which was without pores. In Figure 2D (insertion), the SEM studies of alumina approximately show uniform nonporous structure after modification by MWCNT (Figure 2D), probably via hydrogen bond among alumina and MWCNT leading to a change in porosity and pore diameter that hinders subsequent penetration of species. As expected, such noticeable changes in morphology under constructed scaffold are promising and good indicator for successful modification of alumina scaffold. This will be confirmed in the next section. Surface roughness affects the adsorption of the proteins, along with the cell initial attachment, response, and proliferation. The cellular response is due to protein adsorption and signal induction. The type and strength of the cell attachment rely on the properties of the scaffold, the absorbed proteins, and the proteins produced by the cell. ${ }^{49-51}$ The roughness of the scaffolds was studied by 3D LSM. 3D surface topographies and surface profiles of the FA and NAMC are shown in Figure 3A-D. The surface roughness of substrates in this work is between 3.0 and $10.0 \mathrm{~nm}$ for FA and 87.0 and $125 \mathrm{~nm}$ for NAMC. The modification of alumina nanopore by MWCNT would introduce structures with nano-roughness that, according to Wenzel, would increase surface roughness, shifting a hydrophilic surface toward a superhydrophilic surface. ${ }^{52}$ Surface wettability is an important factor that can determine the protein adsorption and cell response. Surface chemistry is important 


\section{A}
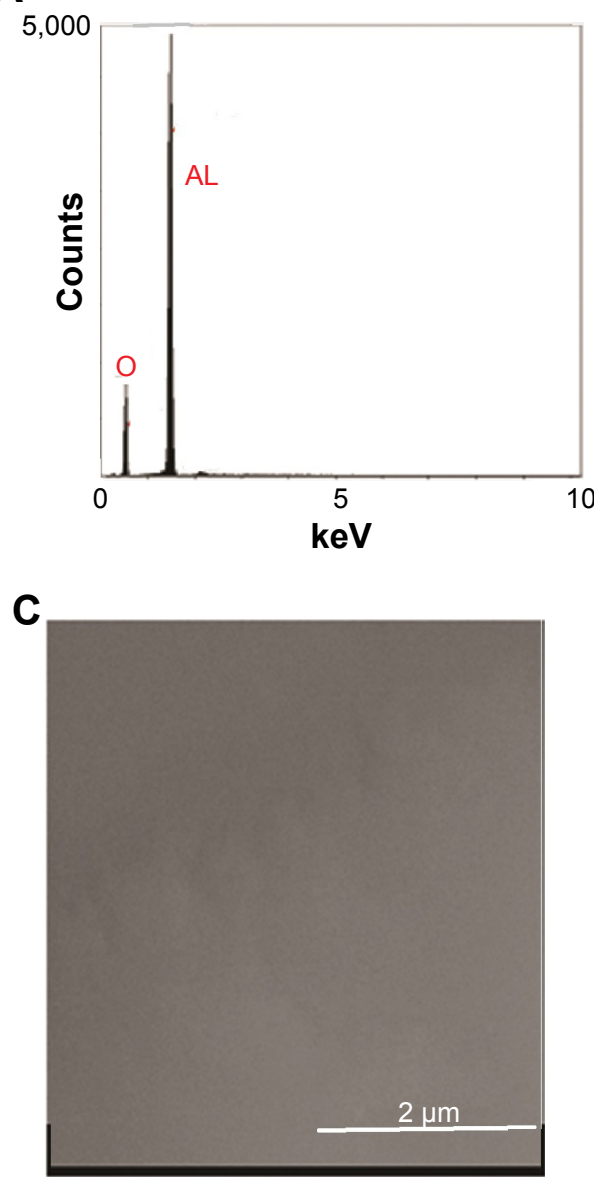

B

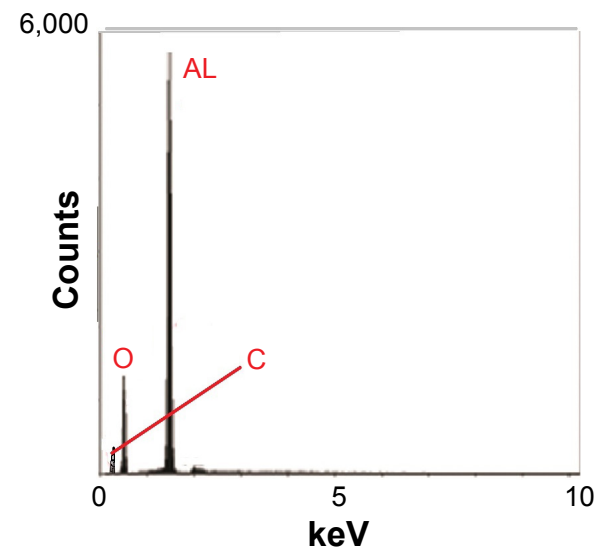

D

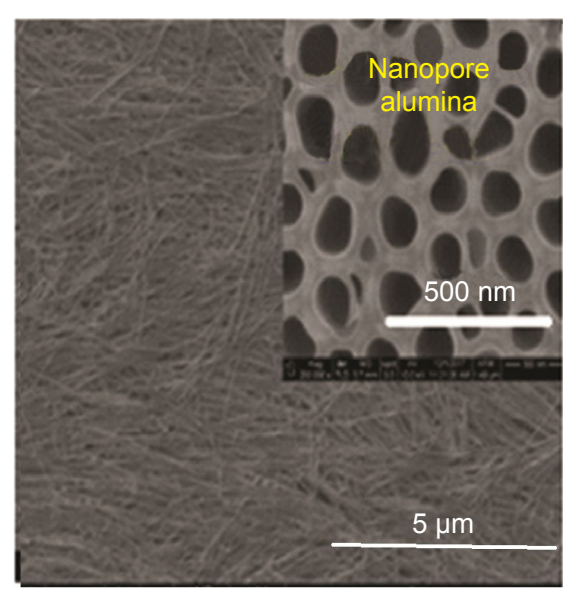

Figure 2 EDAX data of (A) FA and (B) NAMC; scanning electron microscope image of surface of (C) FA and (D) NAMC.

Abbreviations: EDAX, Energy-dispersive x-ray spectroscope; FA, flat alumina; NAMC, nanoporous alumina-multiwalled carbon nanotubes.

in determining the wettability of surface. The WCA and SFE are applied to study substrate surface wettability. The WCA is expressed in degrees $(\theta)$ and is determined by the interaction of adhesive and cohesive forces at two phases of liquid-vapor interface. A water droplet follows the profile of the specimen, as said by Wenzel. ${ }^{53}$

$$
\operatorname{Cos} \theta \mathrm{w}=r \operatorname{Cos} \theta e
$$

In equation, where $\theta$ is apparent $\mathrm{CA}$ and $\theta e$ is the $\mathrm{CA}$ on the flat smooth surface, and the roughness factor " $r$ " is the ratio of the actual solid/liquid contact area to its vertical projection. ${ }^{54}$ In Formula 1, the increment of nano-roughness can alter a hydrophilic surface to superhydrophilic. ${ }^{55}$ In this study, the WCA was $49^{\circ}$ and $10^{\circ}$ for FA and NAMC, respectively (Figure 4). The higher hydrophilicity of the NAMC substrate can be attributed to the modification of substrate by hydrophilic MWCNT that creates hydrophilic groups on the surface and increases nano-roughness. Studies show that the modification increases the SFE from 110.26 for FA to $259.52(\mathrm{mN} / \mathrm{m})$ for NAMAC, which could be related to hydroxyl on the NAMC surface. Scaffolds with less WCA and higher SFE have fewer interactions with the microorganism. Since hydrophilic surfaces have repulsive forces on the foulant absorption, they will have a better anti-biofouling performance.

\section{Protein adsorption on the substrates}

In this study, adsorption of protein on substrates was examined through static BSA adsorption test. Substrate of NAMC showed lower protein adsorption compared with substrate of FA, which may lead to a reduction of biofilm. Protein adsorption for FA and NAMC substrates is $689.54 \mu \mathrm{g} \cdot \mathrm{mL}^{-1} \times$ $\mathrm{cm}^{-2}$ and $96.38 \mu \mathrm{g} \cdot \mathrm{mL}^{-1} \times \mathrm{cm}^{-2}$, respectively. This can be due to more nano-roughness in NAMC substrate, which increases its hydrophilicity. The water barrier mechanism, due to nanoscale roughness, inhibits direct impact between the rough surface and the proteins, thereby, leading to lower 
A

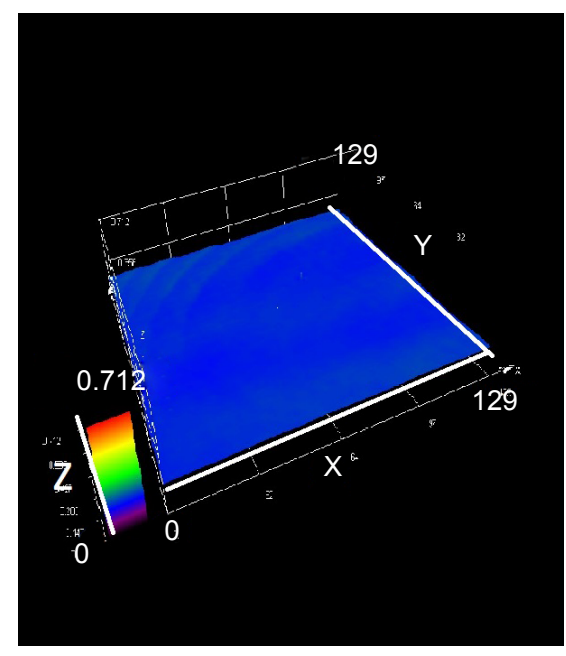

C

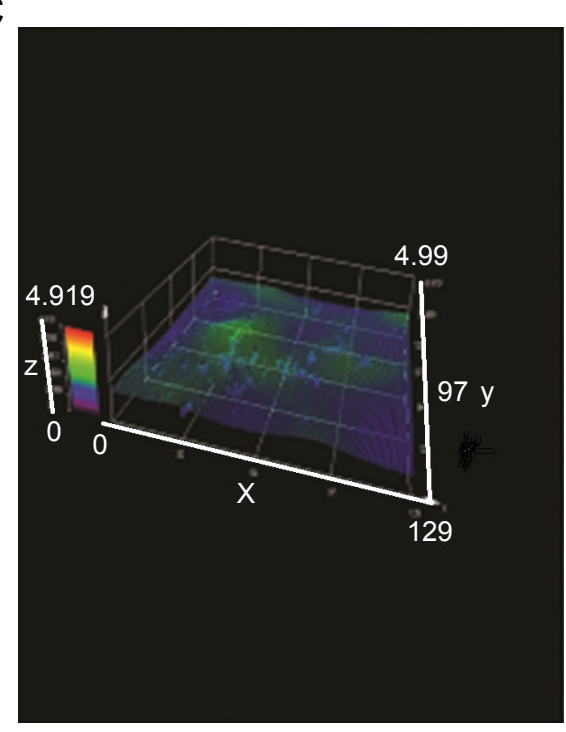

B

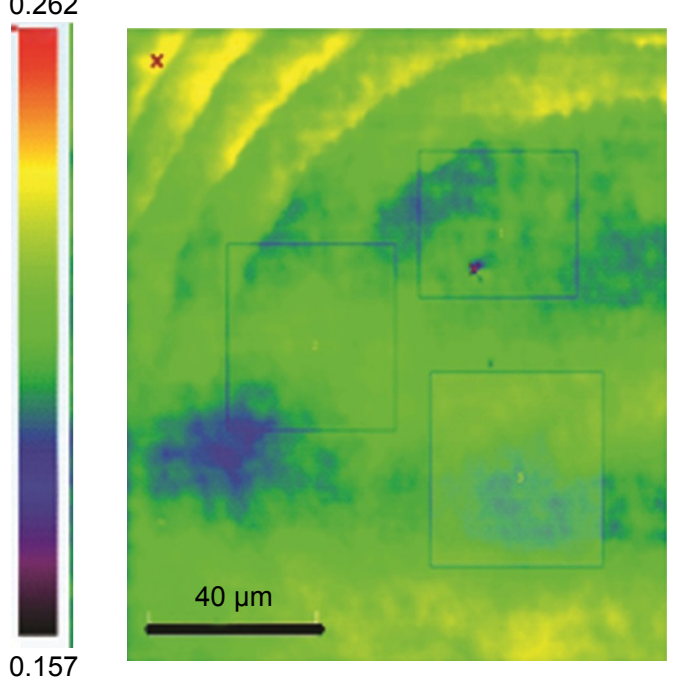

D

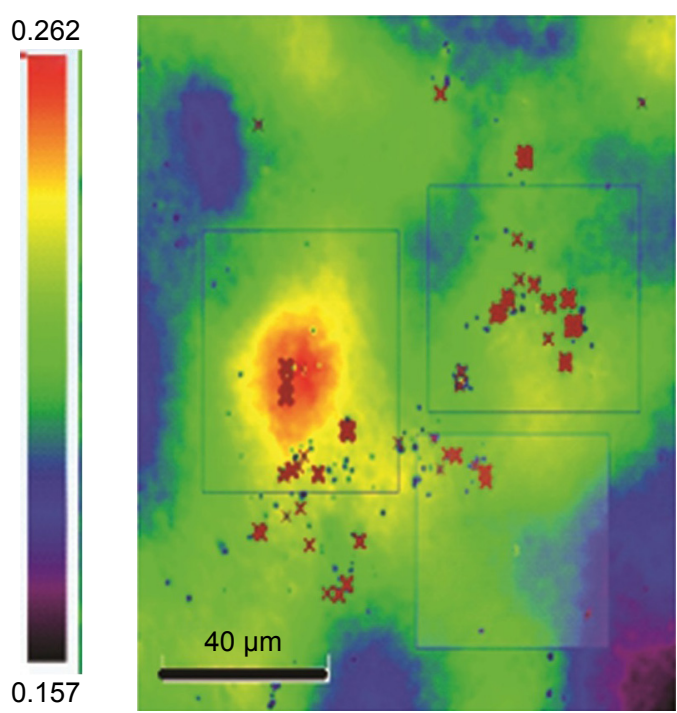

Figure 3 3D Laser scanning microscope showing surface profiles of flat alumina (A and $\mathbf{B}$ ) and nanoporous alumina-multiwalled carbon nanotubes (C and $\mathbf{D})$.

protein adsorption for NAMC. ${ }^{56-58}$ Lower protein adsorptions could be attributed to less attachment of bacteria and reduction of biofilm. ${ }^{59}$ Before the cellular deposition, the types and amounts of proteins adsorbed on the surfaces facilitate cell attachment to their substratum. BSA is more favorably adsorbed onto smooth substratum. BSA strongly binds to surfaces of FA, and preadsorption of BSA onto FA substrate inhibits more cell attachment. ${ }^{26}$
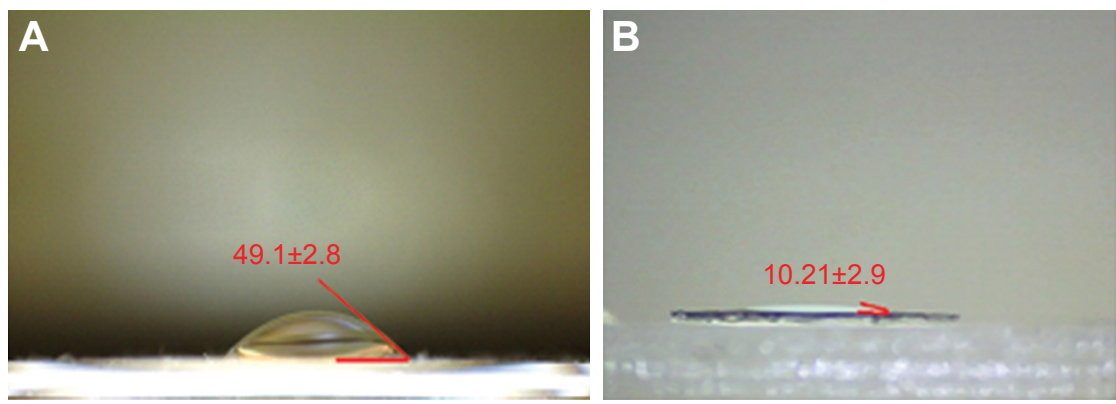

Figure 4 Average of water contact angle of (A) flat alumina and (B) nanoporous alumina-multiwalled carbon nanotubes. 


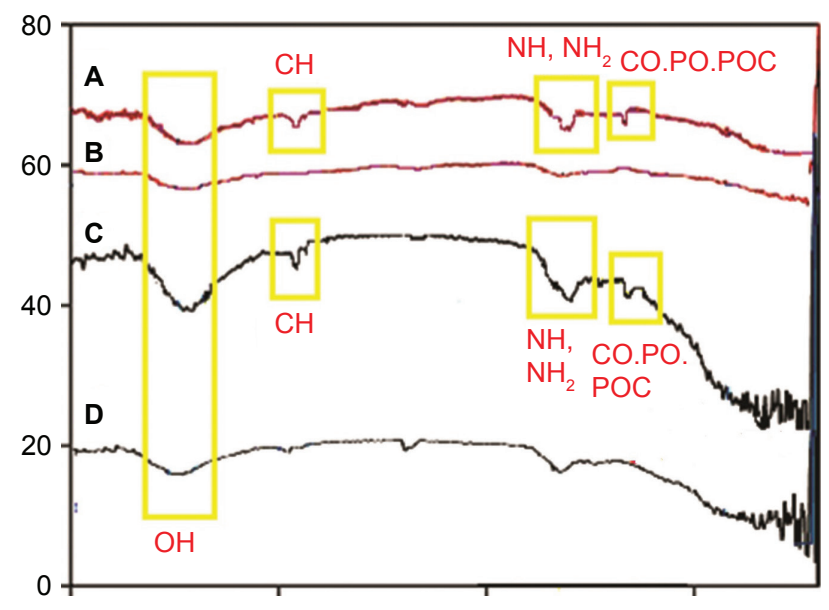

Figure 5 Fourier-transform infrared spectrum of (A) FA-bacteria, (B) FA, (C) NAMC-bacteria and (D) NAMC.

Abbreviations: FA, flat alumina; NAMC, nanoporous alumina-multiwalled carbon nanotubes.

\section{Bacterial attachment}

E. coli and S. aureus are utilized to study the formation of biofilm on the surfaces selected. The substrate of NAMC significantly reduces the bacterial attachment. FTIR results (Figure 5) of FA-E.coli-S.aureus (A) and NAMC-E.coli-S. aureus (C) in comparison to FA (B) and NAMC (D) without bacteria show which bacteria were absorbed on the substrate of FA and NAMC. The characteristic peaks at 3,100-3,400 $\mathrm{cm}^{-1}\left(\mathrm{NH}_{2}\right.$, OH stretching), 2,854 and 2,925 ( $\mathrm{CH}$ stretching), $1,650-1,660\left(-\mathrm{NH}_{2}\right), 1,520(-\mathrm{NH})$, and $1,030-1,150 \mathrm{~cm}^{-1}$ $(\mathrm{C}=\mathrm{O}, P=\mathrm{O}, \mathrm{P}-\mathrm{O})$ confirm which bacteria absorbed on the substrates of FA and NAMC. Figure 6A (FA-E.coli-S.aureus) and 6C (FA-E.coli and FA-S.aureus) are compared to FA without bacteria (Figure 6B), an SEM image shows that biofilm did form on the surface of FA substrate. BSA proteins are further
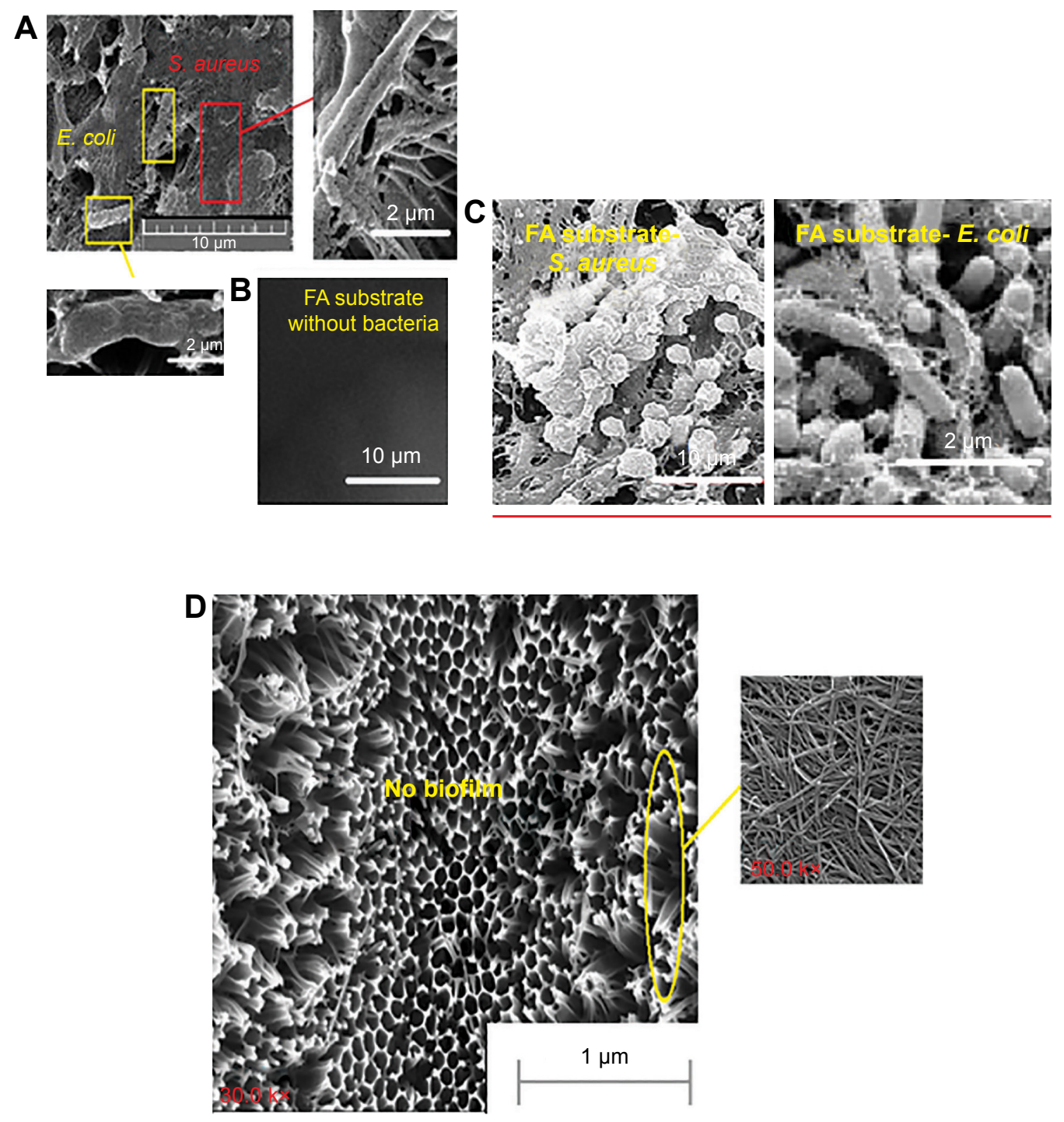

Figure 6 SEM image from (A) surface of FA-E.coli-S.aureus after biofilm assay, (B) surface of virgin FA, (C) FA-E.coli and FA-S.aureus and (D) NAMC after biofilm assay. Abbreviations: E. coli, Escherichia coli; FA, flat alumina; NAMC, nanoporous alumina-multiwalled carbon nanotubes; S. aureus, Staphylococcus aureus. 
attached to the smooth surface $;{ }^{26}$ they may remain trapped and spend a longer dwelling time inside the pore. This will provide an opportunity for other proteins to enter inside the pore, resulting in a compaction effect and a significant reduction in the mean protein-protein distance, thereby increasing nucleation and growth of proteins. ${ }^{60}$ In Figure 6D, the SEM image of NAMC does not contain biofilm. Increasing nano-roughness and hydrophilicity could diminish the interaction between the scaffold and the microorganism, resulting in the decreased biofilm. Also, materials that are carbon-based are able to penetrate through the bacterial cellular membrane, damaging its integrity. ${ }^{55,61-69}$ In NAMC substrate, bacteria are absorbed and CNTs damage their membrane wall, thereby preventing the formation of biofilm. But bacteria absorbed, accumulated, and formed biofilm in the substrate of FA. Figure 7 indicates the finding of flow cytometry assay for the FA (a) and NAMC (b) scaffolds for $E$. coli. The results indicate that the maximum dead bacteria were dedicated to NAMC scaffold.

\section{Cell attachment and proliferation}

SEM images of cell morphology at 24 hours incubation for substrates FA and NAMC are shown in Figure 8A and $\mathrm{B}$, respectively. Cells showed almost good spreading on hydrophilic surfaces of NAMC. Cell spreading in superhydrophilic scaffolds is more significant than other scaffolds. ${ }^{25}$ SEM images of cell proliferation after 7 days incubation for substrates FA and NAMC are shown in Figure $8 \mathrm{C}$ and D, respectively. After 7 days, the cells were proliferating well on substrates NAMC. Cell proliferation increased about tenfold for both surfaces, FA and NAMC, after 1 week of culture. Even though the cells were rounded on the NAMC surface, they had more cytoplasmic extensions, and more networked cells could be found in NAMC. The results of viability assay at both time points show more cells on the surface of NAMC. Figure 9 demonstrates significantly improved fluorescence intensity of DPSCs cultured onto the substrate of NAMC compared with the substrate of FA at 24 hours and 7 days. Statistically significant differences in the results of adherent cells at 24 hours and 7 days of incubation were identified between two substrates of FA and NAMC, with a value of $P<0.05$. Increasing of surface roughness generates a more hydrophilic surface, resulting in decreased albumin and BSA adsorption. The review of the past papers shows
A

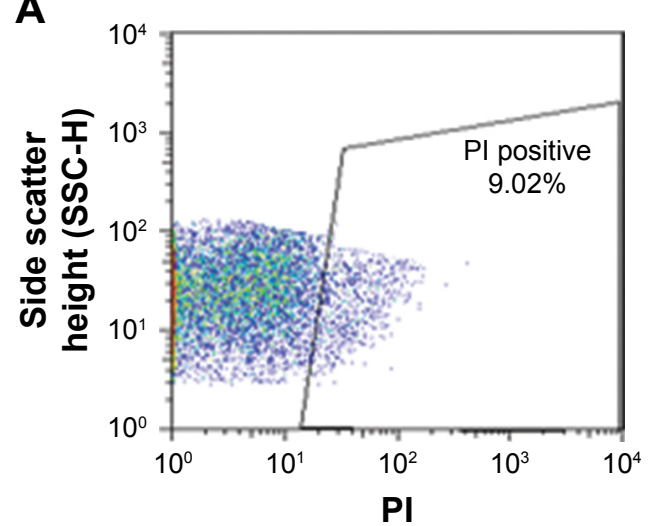

C

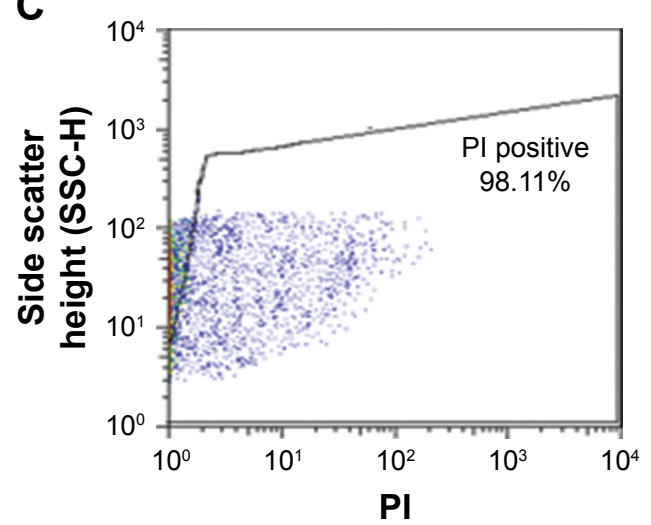

B

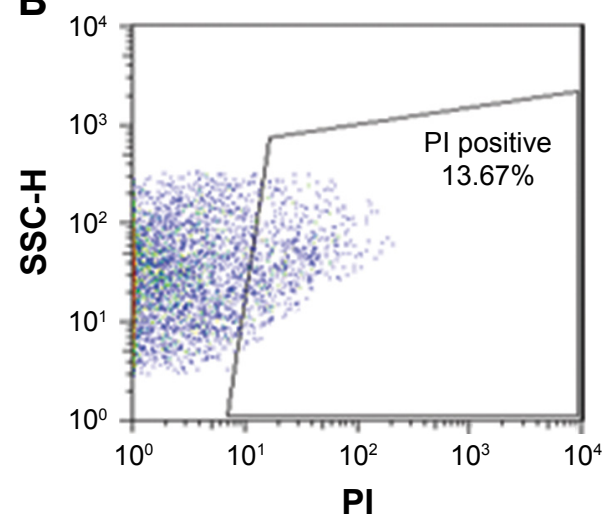

D

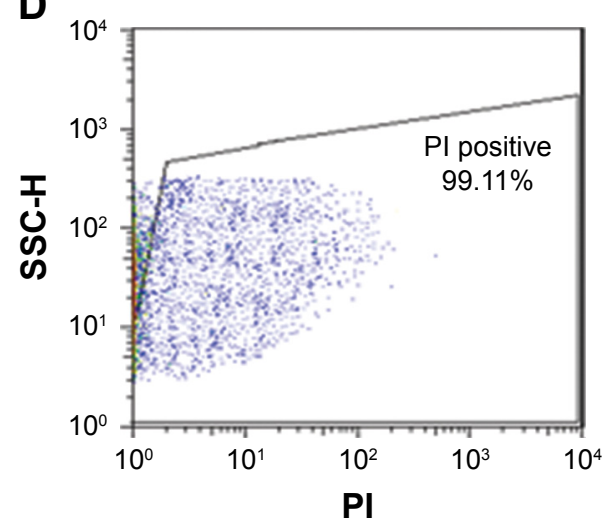

Figure 7 Results of flow cytometry analysis: (A) FA-E. coli, (B) FA-S. aureus, (C) NAMC-E. coli, and (D) NAMC-S. aureus.

Abbreviations: E. coli, Escherichia coli; FA, flat alumina; NAMC, nanoporous alumina-multiwalled carbon nanotubes; PI, propidium iodide; S. aureus, Staphylococcus aureus. 

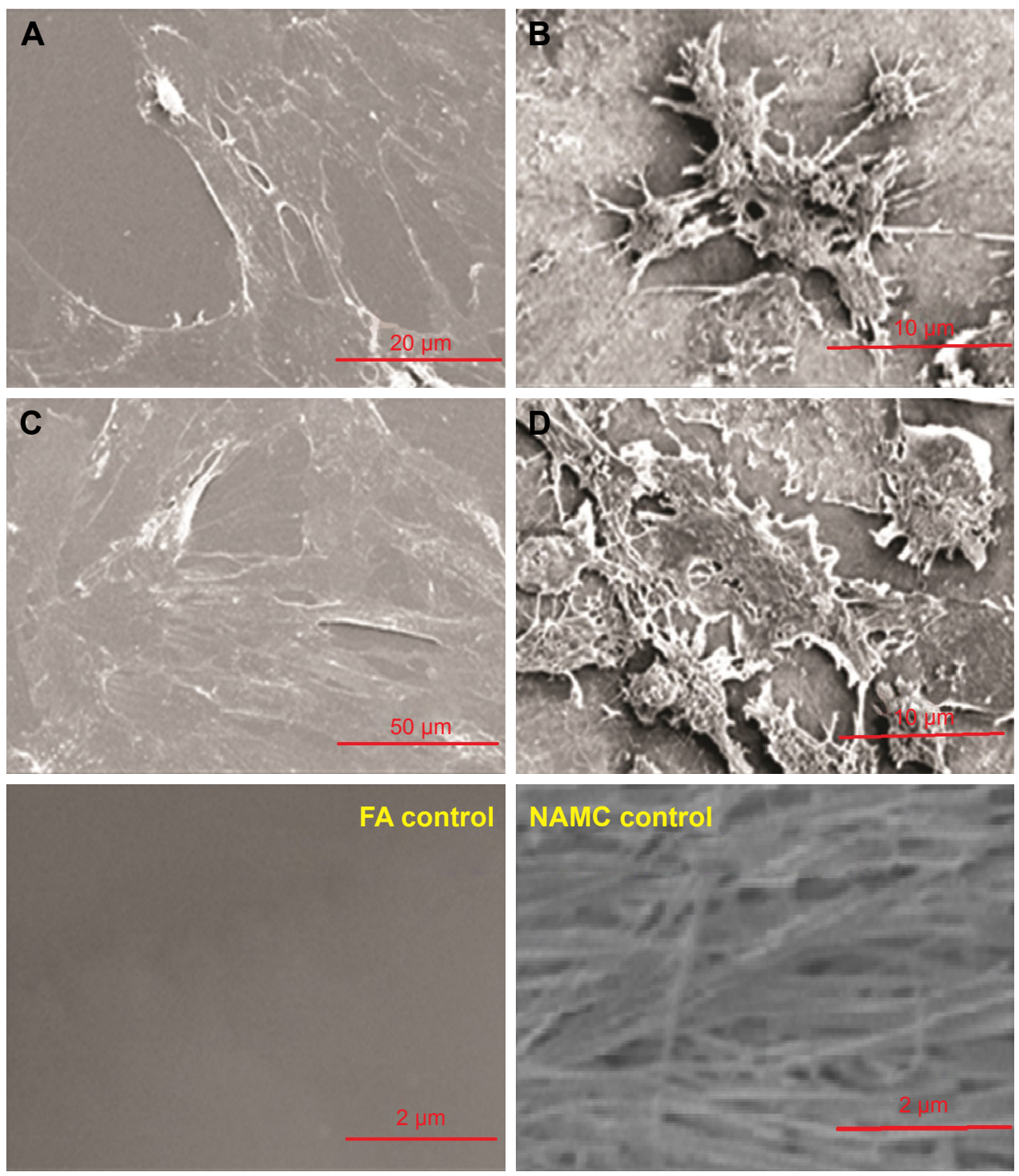

Figure 8 Scanning electron microscope image of cell culture on (A) FA and (B) NAMC after 24 hours, (C) FA, and (D) NAMC after 7 days and control samples. Abbreviations: FA, flat alumina; NAMC, nanoporous alumina-multiwalled carbon nanotubes.

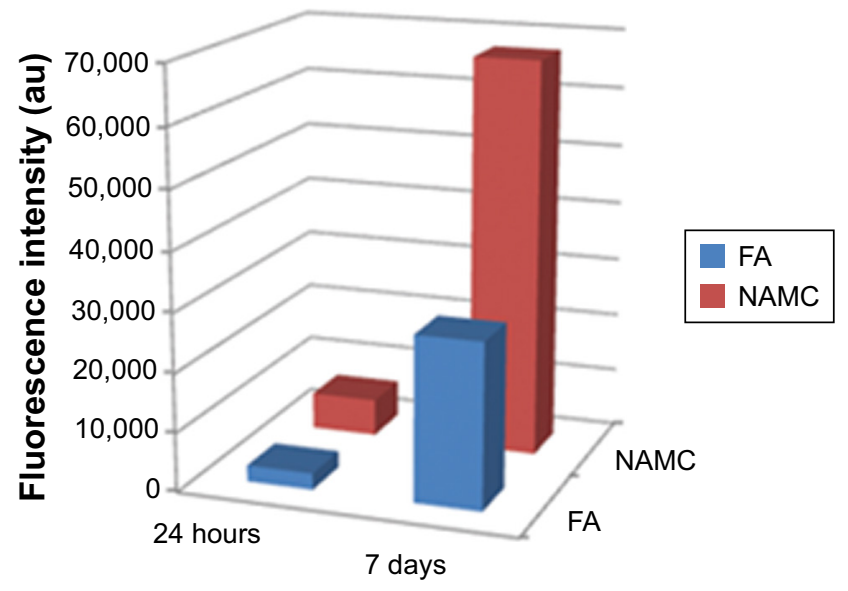

Figure 9 Dental pulp stem cells viability cultured onto flat alumina in comparison with nanoporous alumina-multiwalled carbon nanotubes after 24 hours and 7 days. Abbreviations: FA, flat alumina; NAMC, nanoporous alumina-multiwalled carbon nanotubes. that the rough surface adsorbed more fibronectin and total protein than the flat surface. The enhanced adhesion on rough NAMC could be due to increased fibronectin adsorption onto this substratum. . $6,34,70,71^{2}$

\section{Conclusion}

In this paper, the impact of surface topography and CNT on the cell behavior and proliferation of DPSCs was investigated. DPSCs can be simply obtained in comparison with other SCs. These cells have high proliferative abilities, mineralization ability, self-renewal potential, low immunogenicity, and a multipotent differentiation capacity. DPSCs are useful in tissue repair, cellular, and regenerative therapy. The substrates of nanopore alumina were prepared via anodization technique, and then were modified by CNT. 
SEM characterization and viability assay demonstrated that cell culture increases on the NAMC. The addition of MWCNT to the alumina substrate improved the roughness and hydrophilicity properties. The combination of MWCNT with alumina scaffold improved the anti-biofouling properties of NAMC. The increased cell culture on rough and antimicrobial NAMC could be due to the adsorption of fibronectin onto these scaffolds.

\section{Acknowledgment}

Our research group appreciates all those who collaborated with us in this project.

\section{Disclosure}

The authors report no conflicts of interest in this work.

\section{References}

1. Song Y, Ju Y, Morita Y, Xu B, Song G, et al. Surface functionalization of nanoporous alumina with bone morphogenetic protein 2 for inducing osteogenic differentiation of mesenchymal stem cells. Mater Sci Eng C. 2014;37(37):120-126.

2. Song Y, Ju Y, Song G, Morita Y. In vitro proliferation and osteogenic differentiation of mesenchymal stem cells on nanoporous alumina. Int J Nanomedicine. 2013;8(1):2745-2756.

3. La Noce M, Paino F, Spina A, et al. Dental pulp stem cells: state of the art and suggestions for a true translation of research into therapy. J Dent. 2014;42(7):761-768.

4. Kim K, Evans G. Tissue engineering: the future of stem cells. Top Tissue Eng. 2005;2:1-21.

5. Herberts CA, Kwa MS, Hermsen HP. Risk factors in the development of stem cell therapy. J Transl Med. 2011;9(1):29.

6. Egusa H, Sonoyama W, Nishimura M, Atsuta I, Akiyama K. Stem cells in dentistry-part I: stem cell sources. J Prosthodont Res. 2012;56(3): 151-165.

7. Ledesma-Martínez E, Mendoza-Núñez VM, Santiago-Osorio E. Mesenchymal stem cells derived from dental pulp: a review. Stem Cells Int. 2016;2016(3):1-12.

8. Nuti N, Corallo C, Chan BM, Ferrari M, Gerami-Naini B, et al. Multipotent differentiation of human dental pulp stem cells: a literature review. Stem Cell Rev. 2016;12(5):511-523.

9. Gronthos S, Mankani M, Brahim J, Robey PG, Shi S. Postnatal human dental pulp stem cells (DPSCs) in vitro and in vivo. Proc Natl Acad Sci US A. 2000;97(25):13625-13630.

10. Huang GT, Gronthos S, Shi S. Mesenchymal stem cells derived from dental tissues vs. those from other sources: their biology and role in regenerative medicine. J Dent Res. 2009;88(9):792-806.

11. Wang J, Wang X, Sun Z, et al. Stem cells from human-exfoliated deciduous teeth can differentiate into dopaminergic neuron-like cells. Stem Cells Dev. 2010;19(9):1375-1383.

12. Alge DL, Zhou D, Adams LL, et al. Donor-matched comparison of dental pulp stem cells and bone marrow-derived mesenchymal stem cells in a rat model. J Tissue Eng Regen Med. 2010;4(1):73-81.

13. Jensen J, Tvedesøe C, Rölfing JH, et al. Dental pulp-derived stromal cells exhibit a higher osteogenic potency than bone marrow-derived stromal cells in vitro and in a porcine critical-size bone defect model. Sicot J. 2016;2(18):16.

14. Seo BM, Sonoyama W, Yamaza T, et al. Shed repair critical-size calvarial defects in mice. Oral Dis. 2008;14(5):428-434.

15. Ishizaka R, Iohara K, Murakami M, Fukuta O, Nakashima M. Regeneration of dental pulp following pulpectomy by fractionated stem/ progenitor cells from bone marrow and adipose tissue. Biomaterials. 2012;33(7):2109-2118.
16. Yasui T, Mabuchi Y, Morikawa S, et al. Isolation of dental pulp stem cells with high osteogenic potential. Inflamm Regen. 2017;37(1):8.

17. Miura M, Gronthos S, Zhao M, et al. Shed: Stem cells from human exfoliated deciduous teeth. Proc Natl Acad Sci U S A. 2003;100(10): $5807-5812$.

18. Sonoyama W, Liu Y, Yamaza T, et al. Characterization of the apical papilla and its residing stem cells from human immature permanent teeth: a pilot study. J Endod. 2008;34(2):166-171.

19. Kato T, Hattori K, Deguchi T, et al. Osteogenic potential of rat stromal cells derived from periodontal ligament. J Tissue Eng Regen Med. 2011; 5(10):798-805.

20. Honda MJ, Imaizumi M, Suzuki H, et al. Stem cells isolated from human dental follicles have osteogenic potential. Oral Surg Oral Med Oral Pathol Oral Radiol Endod. 2011;111(6):700-708.

21. Mayo V, Sawatari Y, Huang CY, Garcia-Godoy F. Neural crest-derived dental stem cells - where we are and where we are going. J Dent. 2014; 42(9):1043-1051.

22. Sonoda S, Tomoda E, Tanaka Y, et al. Properties and possibilities of human dental pulp-derived stem cells. Arch Stem Cell Res. 2015; 2(2):1012.

23. Nakashima M, Iohara K, Murakami M. Dental pulp stem cells and regeneration. Endod Topics. 2013;28(1):38-50.

24. Roach P, Eglin D, Rohde K, Perry CC. Modern biomaterials: a reviewbulk properties and implications of surface modifications. J Mater Sci Mater Med. 2007;18(7):1263-1277.

25. Wei J, Igarashi T, Okumori N, et al. Influence of surface wettability on competitive protein adsorption and initial attachment of osteoblasts. Biomed Mater. 2009;4(4):045002.

26. Deligianni DD, Katsala N, Ladas S, et al. Effect of surface roughness of the titanium alloy Ti-6Al-4V on human bone marrow cell response and on protein adsorption. Biomaterials. 2001;22(11):1241-1251.

27. Hoess A, Thormann A, Friedmann A, Heilmann A. Self-supporting nanoporous alumina membranes as substrates for hepatic cell cultures. J Biomed Mater Res A. 2012;100(9):2230-2238.

28. Aramesh M, Cervenka J. Surface modification of porous anodic alumina for medical and biological applications. Nanomedicine. 2015;438: 439-467.

29. Swan EE, Popat KC, Desai TA. Peptide-immobilized nanoporous alumina membranes for enhanced osteoblast adhesion. Biomaterials. 2005;26(14):1969-1976.

30. Hummer G, Rasaiah JC, Noworyta JP. Water conduction through the hydrophobic channel of a carbon nanotube. Nature. 2001;414(6860): 188-190.

31. Namgung S, Kim T, Baik KY, et al. Fibronectin-carbon-nanotube hybrid nanostructures for controlled cell growth. Small. 2011;7(1):56-61.

32. Park SY, Choi DS, Jin HJ, et al. Polarization-controlled differentiation of human neural stem cells using synergistic cues from the patterns of carbon nanotube monolayer coating. ACS Nano. 2011;5(6):4704-4711.

33. Sridharan I, Kim T, Wang R. Adapting collagen/CNT matrix in directing hESC differentiation. Biochem Biophys Res Commun. 2009; 381(4):508-512.

34. Lee JR, Ryu S, Kim S, Kim BS. Behaviors of stem cells on carbon nanotube. Biomater Res. 2015;19(1):3.

35. Chao TI, Xiang S, Lipstate JF, Wang C, Lu J. Poly (methacrylic acid)grafted carbon nanotube scaffolds enhance differentiation of hESCs into neuronal cells. Adv Mater. 2010;22(32):3542-3547.

36. Masuda H, Fukuda K. Ordered metal nanohole arrays made by a twostep replication of honeycomb structures of anodic alumina. Science. 1995;268(5216):1466-1468.

37. van Oss CJ, Chaudhury MK, Good RJ. Monopolar surfaces. Adv Colloid Interface Sci. 1987;28(1):35-64.

38. van Oss CJ, Ju L, Chaudhury MK, Good RJ, et al. Estimation of the polar parameters of the surface tension of liquids by contact angle measurements on gels. J Colloid Interface Sci. 1989;128(2):313-319.

39. Razmjou A, Mansouri J, Chen V, Lim M, Amal R. Titania nanocomposite polyethersulfone ultrafiltration membranes fabricated using a low temperature hydrothermal coating process. J Memb Sci. 2011;380(1-2): $98-113$. 
40. Razmjou A, Mansouri J, Chen V. The effects of mechanical and chemical modification of $\mathrm{TiO} 2$ nanoparticles on the surface chemistry, structure and fouling performance of PES ultrafiltration membranes. J Memb Sci. 2011;378(1-2):73-84.

41. Moazzam P, Razmjou A, Golabi M, Shokri D, Landarani-Isfahani A, et al. Investigating the BSA protein adsorption and bacterial adhesion of Al-alloy surfaces after creating a hierarchical (micro/nano) superhydrophobic structure. J Biomed Mater Res A. 2016;104(9):2220-2233.

42. Orooji Y, Liang F, Razmjou A, et al. Excellent biofouling alleviation of thermoexfoliated vermiculite blended poly (ether sulfone) ultrafiltration membrane. ACS Appl Mater Interfaces. 2017;9(35):30024-30034.

43. Li J, Wang X, Wang L, et al. Preparation of alumina membrane from aluminium chloride. J Memb Sci. 2006;275(1-2):6-11.

44. Li WL, Tian SB, Zhu F. Sulfonic acid functionalized nano- $\hat{\mathrm{I}}^{3}-\mathrm{Al}_{2} \mathrm{O}_{3}$ : a new, efficient, and reusable catalyst for synthesis of 3-substituted2H-1, 4-benzothiazines. Sci World J. 2013;2013:838374.

45. Costa HDS, Pereira MME, Andrade GI, et al. Characterization of calcium phosphate coating and zinc incorporation on the porous alumina scaffolds. J Mater Res. 2007;10(1):27-29.

46. Chang CS, Suen SY. Modification of porous alumina membranes with n-alkanoic acids and their application in protein adsorption. J Memb Sci. 2006;275(1-2):70-81.

47. Małgorzata N, Krasinski A. Controlling of water wettability by structural and chemical modification of porous anodic alumina (PAA): towards super-hydrophobic surfaces. Surf Coat Technol. 2015;276:464-470.

48. Leitao DC, Ventura J, Sousa CT, et al. Tailoring the physical properties of thin nanohole arrays grown on flat anodic aluminum oxide templates. Nanotechnology. 2012;23(42):425701.

49. Lampin M, Warocquier-Clérout, Legris C, Degrange M, Sigot-Luizard MF. Correlation between substratum roughness and wettability, cell adhesion, and cell migration. J Biomed Mater Res. 1997;36(1):99-108.

50. Goldberg VM, Jinno T. The bone-implant interface: a dynamic surface. J Long Term Eff Med Implants. 1999;9(1-2):11-21.

51. Valagão Amadeu do Serro AP, Fernandes AC, de Jesus Vieira Saramago B, Norde W. Bovine serum albumin adsorption on titania surfaces and its relation to wettability aspects. J Biomed Mater Res. 1999;46(3):376-381.

52. Wenzel RN. Surface roughness and contact angle. J Phys Chem. 1949; 53(9):1466-1467.

53. Zheng J, Li L, Chen S, Jiang S. Molecular simulation study of water interactions with oligo (ethylene glycol)-terminated alkanethiol selfassembled monolayers. Langmuir. 2004;20(20):8931-8938.

54. Zhu Y, Ding G, Ding J, Yuan N. AFM, SEM and TEM studies on porous anodic alumina. Nanoscale Res Lett. 2010;5(4):725-734.

55. Orooji Y, Faghih M, Razmjou A, et al. Nanostructured mesoporous carbon polyethersulfone composite ultrafiltration membrane with significantly low protein adsorption and bacterial adhesion. Carbon. 2017; 111:689-704.
56. Pertsin AJ, Grunze M. Computer simulation of water near the surface of oligo (ethylene glycol)-terminated alkanethiol self-assembled monolayers. Langmuir. 2000;16(23):8829-8841.

57. Archambault JG, Brash JL. Protein repellent polyurethane-urea surfaces by chemical grafting of hydroxyl-terminated poly (ethylene oxide): effects of protein size and charge. Colloids Surf B Biointerfaces. 2004; 33(2):111-120.

58. Hou J, Dong G, Ye Y, Chen V. Enzymatic degradation of bisphenol-A with immobilized laccase on $\mathrm{TiO}_{2}$ sol-gel coated PVDF membrane. J Memb Sci. 2014;469:19-30.

59. Orooji Y, Liang F, Razmjou A, Liu G, Jin W. Preparation of antiadhesion and bacterial destructive polymeric ultrafiltration membranes using modified mesoporous carbon. Sep Purif Technol. 2018;205: $273-283$.

60. Chayen NE, Saridakis E, Sear RP. Experiment and theory for heterogeneous nucleation of protein crystals in a porous medium. Proc Natl Acad Sci U S A. 2006;103(3):597-601.

61. Hou J, Ji C, Dong G, et al. Biocatalytic Janus scaffold for $\mathrm{CO}_{2}$ removal utilizing carbonic anhydrase. JMater Chem A. 2015;3(33):17032-17041.

62. Maleki Dizaj S, Mennati A, Jafari S, Khezri K, Adibkia K. Antimicrobial activity of carbon-based nanoparticles. Adv Pharm Bull. 2015; 5(1):19-23.

63. Arias LR, Yang L. Inactivation of bacterial pathogens by carbon nanotubes in suspensions. Langmuir. 2009;25(5):3003-3012.

64. Muller J, Huaux F, Moreau N, et al. Respiratory toxicity of multi-wall carbon nanotubes. Toxicol Appl Pharmacol. 2005;207(3):221-231.

65. Magrez A, Kasas S, Salicio V, et al. Cellular toxicity of carbon-based nanomaterials. Nano Lett. 2006;6(6):1121-1125.

66. Shvedova AA, Kisin ER, Porter D, et al. Mechanisms of pulmonary toxicity and medical applications of carbon nanotubes: two faces of Janus? Pharmacol Ther. 2009;121(2):192-204.

67. Upadhyayula VK, Gadhamshetty V. Appreciating the role of carbon nanotube composites in preventing biofouling and promoting biofilms on material surfaces in environmental engineering: a review. Biotechnol Adv. 2010;28(6):802-816.

68. Kang S, Pinault M, Pfefferle LD, Elimelech M, et al. Single-walled carbon nanotubes exhibit strong antimicrobial activity. Langmuir. 2007;23(17):8670-8673.

69. Kang S, Herzberg M, Rodrigues DF, Elimelech M. Antibacterial effects of carbon nanotubes: size does matter! Langmuir. 2008;24(13): 6409-6413.

70. Mooney E, Dockery P, Greiser U, Murphy M, Barron V. Carbon nanotubes and mesenchymal stem cells: biocompatibility, proliferation and differentiation. Nano Lett. 2008;8(8):2137-2143.

71. Stout DA, Webster TJ. Carbon nanotubes for stem cell control. Mater Today. 2012;15(7-8):312-318. 


\section{Supplementary material}

Table SI Parameters of acid-base Van Oss method

\begin{tabular}{|l|l|l|l|l|}
\hline Liquid & SFT $(\mathbf{m N} / \mathbf{m})$ & $\sigma^{\text {disperse }}(\mathbf{m N} / \mathbf{m})$ & Acid $(\mathbf{m N} / \mathbf{m})$ & Base $(\mathbf{m N} / \mathbf{m})$ \\
\hline Milli-Q water & 72.8 & 21.8 & 25.5 & 25.5 \\
\hline Glycerol & 64.0 & 34.0 & 3.9 & 57.4 \\
\hline Formamide & 58.0 & 39.0 & 23.2 & 23.2 \\
\hline
\end{tabular}

Abbreviation: SFT, surface tension.

\section{Publish your work in this journal}

The International Journal of Nanomedicine is an international, peerreviewed journal focusing on the application of nanotechnology in diagnostics, therapeutics, and drug delivery systems throughout the biomedical field. This journal is indexed on PubMed Central, MedLine, CAS, SciSearch ${ }^{\circledR}$, Current Contents ${ }^{\circledR} /$ Clinical Medicine,

Journal Citation Reports/Science Edition, EMBase, Scopus and the Elsevier Bibliographic databases. The manuscript management system is completely online and includes a very quick and fair peer-review system, which is all easy to use. Visit http://www.dovepress.com/ testimonials.php to read real quotes from published authors.

Submit your manuscript here: http://www.dovepress.com/international-journal-of-nanomedicine-journal 